〔J. Appl. Glycosci., Vol. 47, No. 2, p. 177-185 (2000)]

\title{
Purification and Characterization of an Endo-cellulase from Acremonium cellulolyticus
}

\author{
Supannee Kansarn, ${ }^{1}$ Naoyoshi Matsushita, ${ }^{2}$ Toshiaki Kono ${ }^{3}$ and Gentaro Okada ${ }^{1,2, *}$ \\ ${ }^{1}$ The Graduate School of Electronic Science and Technology, Shizuoka University \\ (3-5-1, Johoku, Hamamatsu 432-8561, Japan) \\ ${ }^{2}$ Department of Biology, Faculty of Education, Shizuoka University (836, Ohya, Shizuoka 422-8529, Japan) \\ ${ }^{3}$ Bio Science Laboratories, Meiji Seika Kaisha, Ltd. (5-3-1, Chiyoda, Sakado 350-0289, Japan)
}

\begin{abstract}
An endo-cellulase from a commercial cellulase preparation of a filamentous fungus Acremonium cellulolyticus was separated and extensively purified to essential homogeneity by using consecutive column chromatographies of QAE-Toyopearl 550C, DEAE-Toyopearl 650S, Butyl-Toyopearl $650 \mathrm{M}$ and Bio-Gel P-100, and was designated as cellulase IV. The purified enzyme was homogeneous on both Native- and SDS-PAGE, and was completely free from $\beta$-glucosidase. The enzyme showed high specific activity for CMC and an extremely low specific activity for Avicel (a microcrystalline cellulose powder), 106 and $0.08 \mathrm{U} / \mathrm{mg}$ of protein, respectively. The molecular mass of the enzyme was estimated to be about $38 \mathrm{kDa}$ by SDS-PAGE. The enzyme was an acidic protein with a $\mathrm{p} I$ value of $\leqq 3.4$. The $\mathrm{N}$-terminal amino acid sequence from the 2 nd up to the 27 th residue of the purified cellulase was Gln-Ala-Ser-(Cys)-Phe-Glu-Trp-Phe-Gly-Ser-Asn-Glu-Ser-GlyAla-Glu-Phe-Gly-Ser-Gly-Asn-Ile-Pro-Gly-Val-Glu-. The optimum $\mathrm{pH}$ and temperature were 4.0 and $60^{\circ} \mathrm{C}$, respectively. The enzyme was completely stable over the range of $\mathrm{pH} 5.0-12.0$ at $4^{\circ} \mathrm{C}$ for $24 \mathrm{~h}$ and at temperatures below $50^{\circ} \mathrm{C}$. Cellulase IV was characterized as a medium endo-type cellulase on the basis of its action on CMC and cellooligosaccharides. The enzyme was completely inhibited by $5 \mathrm{mM} \mathrm{Hg}^{2+}, \mathrm{Fe}^{3+}$ and $\mathrm{KMnO}_{4}$. Cellulase IV split various cellulosic substrates to produce predominant cellobiose and a small amount of glucose as the final hydrolysis products.
\end{abstract}

The main deterioration of cellulose is caused by cellulolytic microbes, and the biological degradation of highly ordered native cellulose is an extremely important process for the maintenance of the carbon balance in nature. Since crystalline cellulose is an insoluble substance with a supramolecular structure, the enzymological approach to this substrate is rather complicated and difficult. In

\footnotetext{
${ }^{*}$ Corresponding author.

Abbreviations: QAE, quaternary aminoethyl; DEAE, diethylaminoethyl; PAGE, polyacrylamide gel electrophoresis; SDS, sodium dodecyl sulfate; CMC, sodium carboxymethylcellulose; PNPG, $p$-nitrophenyl $\beta$-D-glucoside; $\overline{\mathrm{DS}}$, degree of substitution; $\mathrm{G}_{1}$, D-glucose; $\mathrm{G}_{2-}$ $\mathrm{G}_{6}$, cellooligosaccharides from cellobiose to cellohexaose; NBS, $N$-bromosuccinimide; EDTA, ethylenediaminetetraacetic acid; HPLC, high-pressure liquid chromatography.
}

most cellulolytic microorganisms, several cellulase $[1,4-(1,3 ; 1,4)-\beta$-D-glucan-4-glucanohydrolase, EC 3.2.1.4] components together constitute a "cellulase system" that solubilizes native cellulose through their synergistic action. ${ }^{1)}$

We have presented a series of reports on the cellulase system of Trichoderma viride ${ }^{2-8)} \mathrm{We}$ are at present focusing our research efforts on the complete elucidation of the mechanism involved in the enzymatic degradation of native cellulose. Recently, we found that the commercial cellulase preparation of Acremonium cellulolyticus possessed extremely potent activity toward native cellulose. Little is known about the cellulase system of this filamentous fungus.

This paper describes the purification, physicochemical and enzymic properties of an endo-cellulase from A. cellulolyticus. 


\section{MATERIALS AND METHODS}

Enzyme material. The commercial cellulase preparation from the culture filtrate of $A$. cellulolyticus (Acremonium cellulase, lot No. AUS0301, Meiji Seika Kaisha, Ltd., Japan) was used in this work.

Materials. Sodium carboxymethylcellulose (CMC), Cellogen WS-C ( $\overline{\mathrm{DS}}=0.62-0.68)$, was kindly supplied from Daiichi Industrial Pharmaceutical Co., Ltd., Japan, a microcrystalline cellulose powder (Avicel) was obtained from Asahi Kasei Co., Ltd., Japan, and $p$-nitrophenyl $\beta$-D-glucoside (PNPG) was a product of Tokyo Kasei Kogyo Co., Ltd., Japan. Dewaxed cotton was a product of Japanese Pharmacopoeial Standard, manufactured by Warabieizai Co., Ltd., Japan, and Whatman No.1 filter paper was from Whatman International, Ltd., England. Cellooligosaccharides $\left(\mathrm{G}_{3}-\mathrm{G}_{6}\right)$ were products of Seikagaku Kogyo Co., Ltd., Japan, and cellobiose $\left(\mathrm{G}_{2}\right)$ was from Sigma Chemical Co., Ltd., USA. Pyroglutamate aminopeptidase from Pyrococcus furiosus was a product of Takara Shuzo Co., Ltd., Japan. QAE-Toyopearl 550C, DEAE-Toyopearl 650S and Butyl-Toyopearl $650 \mathrm{M}$ were the products of Tosoh, Japan, and BioGel P-100 was from Bio-Rad Laboratories, USA. Polyacrylamide slab gel (PAGEL, NPU-12.5 L) was a product of Atto Co., Ltd., Japan. SDSPAGE molecular mass standards (low range of 14.4 to $97.4 \mathrm{kDa}$ ) were products of Bio-Rad Laboratories, USA, and Coomassie Brilliant Blue R-250 was a product of Nakarai Chemical Ltd., Japan. Ampholine PAGplate $(\mathrm{pH} 3.5-9.5 ; 245 \times 110 \times 1$ $\mathrm{mm}$ ) and IEF Calibration Broad $\mathrm{pI}$ Kit (pH 3-10) were products of Amersham Pharmacia Biotech, Sweden. All other reagents were of analytical grade.

\section{Enzyme assays.}

(a) CMC-saccharification activity. CMC-saccharification activity was used as a standard assay. The reaction mixture for CMC-saccharification assay contained $0.25 \mathrm{~mL}$ of $1 \% \mathrm{CMC}$ solution, 0.5 $\mathrm{mL}$ of $50 \mathrm{mM}$ acetate buffer (pH 5.0), and 0.25 $\mathrm{mL}$ of the enzyme solution. The mixture was incubated at $30^{\circ} \mathrm{C}$ for an appropriate period. Reducing sugars produced per $1.0 \mathrm{~mL}$ of the mixture were estimated by the colorimetric method of Somogyi ${ }^{9)}$ and Nelson. ${ }^{10)}$

(b) Avicel-saccharification activity. The reaction mixture was comprised of $40 \mathrm{mg}$ of Avicel powder and $2.0 \mathrm{~mL}$ of enzyme solution in $50 \mathrm{mM}$ acetate buffer ( $\mathrm{pH}$ 5.0). Incubation was carried out at $40^{\circ} \mathrm{C}$ for an appropriate period. The reaction was stopped by the addition of $20 \mu \mathrm{L}$ of $2 \mathrm{~N}$ $\mathrm{NaOH}$ solution. After centrifugation of the mixture at $3500 \mathrm{rpm}$ for $20 \mathrm{~min}, 1.0 \mathrm{~mL}$ of the supernatant was carefully withdrawn and analyzed for reducing sugars by the colorimetric method of SomogyiNelson.

One unit (U) of each saccharification activity was defined as the amount of enzyme liberating reducing sugars equivalent to $1.0 \mu \mathrm{mol} / \mathrm{min}$ of $\mathrm{D}$ glucose from the substrate under these conditions.

(c) Aryl $\beta$-glucosidase activity. The reaction mixtures, containing $0.05 \mathrm{~mL}$ of $13.6 \mathrm{mM}$ PNPG, $0.10 \mathrm{~mL}$ of $50 \mathrm{mM}$ acetate buffer $(\mathrm{pH} 5.0)$ and $0.05 \mathrm{~mL}$ of enzyme solution, was incubated at $30^{\circ} \mathrm{C}$ for an appropriate period. The reaction was stopped by the addition of $5 \mathrm{~mL}$ of $100 \mathrm{mM}$ $\mathrm{Na}_{2} \mathrm{CO}_{3}$ to the mixture $(0.20 \mathrm{~mL})$, and then the amount of $p$-nitrophenol liberated was colorimetrically measured by absorbance at $420 \mathrm{~nm}$. One unit (U) of the enzyme activity was defined as the amount of enzyme that produces $1.0 \mu \mathrm{mol}$ of $p$ nitrophenol under these assay conditions.

Measurement of protein and carbohydrate. Protein content was measured by the method of Lowry et al.$^{11)}$ with crystalline bovine serum albu$\min$ as a standard. Absorbance at $280 \mathrm{~nm}$ was used for monitoring protein in column effluents.

The total carbohydrate in the purified enzyme was determined by the phenol-sulfuric acid method $^{12)}$ with D-glucose as a standard.

Electrophoresis. Polyacrylamide gel electrophoresis (PAGE) was done in $12.5 \%$ polyacrylamide with Tris-glycine buffer ( $\mathrm{pH}$ 6.8) according to the method of Davis. ${ }^{13)}$ SDS-PAGE was done in $12.5 \%$ polyacrylamide containing $0.1 \%$ SDS by the method of Laemmli. ${ }^{14)}$ In both cases, the gels were stained with $0.05 \%$ Coomassie Brilliant Blue R-250 for $1 \mathrm{~h}$ and decoloured with $8.0 \%(\mathrm{v} / \mathrm{v})$ acetic acid until the background be- 
came clear. The $\mathrm{p} I$ value was determined by the method of Vesterberg ${ }^{15)}$ using Ampholine PAGplate (pH 3.5-9.5) and a LKB Multiphor II Electrophoresis Unit (Model 2117). Standard proteins with $\mathrm{p} I$ values ranging from 3 to 10 (Pharmacia Biotech) were run simultaneously. Gels were stained with $0.25 \%$ Coomassie Brilliant Blue R250 for $10 \mathrm{~min}$ and destained with $8.0 \%(\mathrm{v} / \mathrm{v})$ acetic acid until the background became clear.

Analysis of $\boldsymbol{N}$-terminal amino acid sequence. The N-terminal amino acid sequence of the purified enzyme was analyzed by N-terminal Edman degradation employing a protein sequencer, $\mathrm{PE}$ Model 492 (Perkin-Elmer Co., USA).

Viscometry. The changes in viscosity during the enzymatic hydrolysis of CMC were measured at intervals with a Cannon-Fenske viscometer $(c=$ 0.0369). The enzyme activity was expressed in terms of specific fluidity ( $\phi_{\text {sp. }}$ ).

High pressure liquid chromatography (HPLC). Cellooligosaccharides were separated and identi- fied by HPLC on a Shimadzu LC-10 system with a LC-10AD pump (Shimadzu Corporation), RID6A refractive index detector (Shimadzu Corporation), and C-R7A integrator (Shimadzu Corporation) under the following conditions: column, Aminex HPX-42A $(7.8 \times 300 \mathrm{~mm}$, Bio-Rad Laboratories); column temperature, $80^{\circ} \mathrm{C}$; mobile phase, deionized water; and flow rate, $0.6 \mathrm{~mL} / \mathrm{min}$.

\section{RESULTS}

\section{Purification of the enzyme.}

Unless otherwise stated, all purification procedures for the enzyme were done in a cold room $\left(4{ }^{\circ} \mathrm{C}\right)$.

Commercial cellulase powder $(5 \mathrm{~g})$ was mixed with $50 \mathrm{~mL}$ of $20 \mathrm{mM}$ acetate buffer (pH 5.5) by carefully stirring overnight at $4^{\circ} \mathrm{C}$. The crude enzyme extract was centrifuged at $2000 \times g$ for 20 min at $4^{\circ} \mathrm{C}$. The resulting supernatant was used as a starting enzyme material for purification.

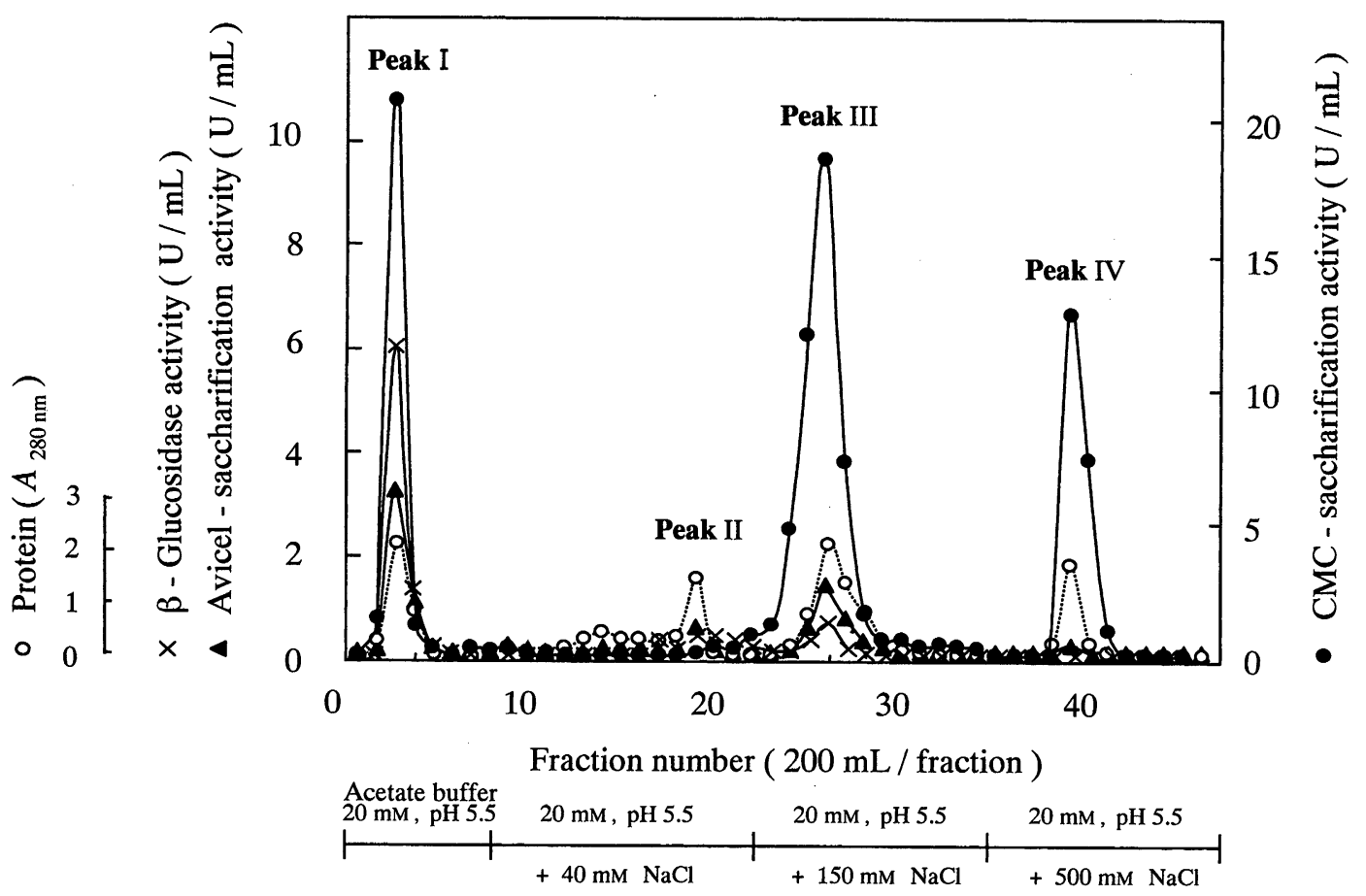

Fig. 1. Elution profiles of the crude cellulase preparation on QAE-Toyopearl 550C column chromatography.

$\bigcirc$, protein $\left(A_{280 \mathrm{~nm}}\right) ; \boldsymbol{O}, \mathrm{CMC}$-saccharification activity $(\mathrm{U} / \mathrm{mg}$ protein) $; \boldsymbol{\Delta}$, Avicel-saccharification activity $(\mathrm{U} / \mathrm{mg}$ protein $) ; \times, \beta$-glucosidase activity $(\mathrm{U} / \mathrm{mg}$ protein). 
Step 1. QAE-Toyopearl 550C column chromatography. The starting enzyme material was put on a QAE-Toyopearl $550 \mathrm{C}$ column $(4 \times 28.5 \mathrm{~cm})$ pre-equilibrated with $20 \mathrm{mM}$ acetate buffer $(\mathrm{pH}$ 5.5). Elution was done stepwise with the same buffer containing $0,40,150$ and $500 \mathrm{mM} \mathrm{NaCl}$ at a flow rate of $3 \mathrm{~mL} / \mathrm{min}$. Each $200 \mathrm{~mL}$ fraction was collected and assayed for cellulase activity. Four protein peaks (Peaks I-IV) were obtained (Fig. 1). Three peak fractions (Peaks I, III and IV) showed cellulase activity toward CMC (Fig. 1). Among them, the peak IV fraction had a potent cellulase activity without $\beta$-glucosidase activity. Therefore, the peak IV fraction (fraction Nos. 3941) was collected and concentrated to about 15 $\mathrm{mL}$ by ultrafiltration with a Diaflo PM10 membrane (Amicon Corp., USA) and collodion bag (Sartorius $\mathrm{GmBH}$ ), and dialyzed overnight against $20 \mathrm{mM}$ acetate buffer (pH 5.5).

Step 2. DEAE-Toyopearl 650S column chromatography. The dialyzed sample was put on a DEAE-Toyopearl $650 \mathrm{~S}$ column $(4 \times 36 \mathrm{~cm})$ preequilibrated with $20 \mathrm{mM}$ acetate buffer (pH 5.5). Elution was done stepwise with the same buffer containing 0,100 and $150 \mathrm{mM} \mathrm{NaCl}$ at a flow rate of $0.2 \mathrm{~mL} / \mathrm{min}$. Each $10 \mathrm{~mL}$ fraction was collected and assayed for cellulase activity. The active fractions were pooled, concentrated, and dialyzed overnight against $20 \mathrm{mM}$ acetate buffer $(\mathrm{pH}$ 4.5) containing $700 \mathrm{mM}\left(\mathrm{NH}_{4}\right)_{2} \mathrm{SO}_{4}$.

Step 3. Butyl-Toyopearl 650M column chromatography. The dialyzed sample was put on a Butyl-Toyopearl $650 \mathrm{M}$ column $(2 \times 30 \mathrm{~cm})$ preequilibrated with $20 \mathrm{mM}$ acetate buffer $(\mathrm{pH} 4.5)$ containing $700 \mathrm{mM}\left(\mathrm{NH}_{4}\right)_{2} \mathrm{SO}_{4}$. Stepwise elution was done with the same buffer containing $700 \mathrm{mM}$ $\left(\mathrm{NH}_{4}\right)_{2} \mathrm{SO}_{4}, 20 \mathrm{mM}$ acetate buffer $(\mathrm{pH} \mathrm{4.5)}$ and distilled water, respectively. Each $6 \mathrm{~mL}$ fraction was collected at a flow rate of $0.5 \mathrm{~mL} / \mathrm{min}$ and assayed for cellulase activity. The active fraction was eluted only with $20 \mathrm{mM}$ acetate buffer $(\mathrm{pH}$ 4.5). Fractions containing cellulase activity were pooled, concentrated and dialyzed overnight against $20 \mathrm{mM}$ acetate buffer ( $\mathrm{pH} 5.5)$.

Step 4. Bio-Gel P-100 column chromatography.

The dialyzed sample was loaded on a Bio-Gel P100 column $(2 \times 42 \mathrm{~cm})$ pre-equilibrated with 20 $\mathrm{mM}$ acetate buffer ( $\mathrm{pH}$ 5.5). The enzyme was eluted with the same buffer at a flow rate of 0.1 $\mathrm{mL} / \mathrm{min}$. A symmetrical protein peak containing

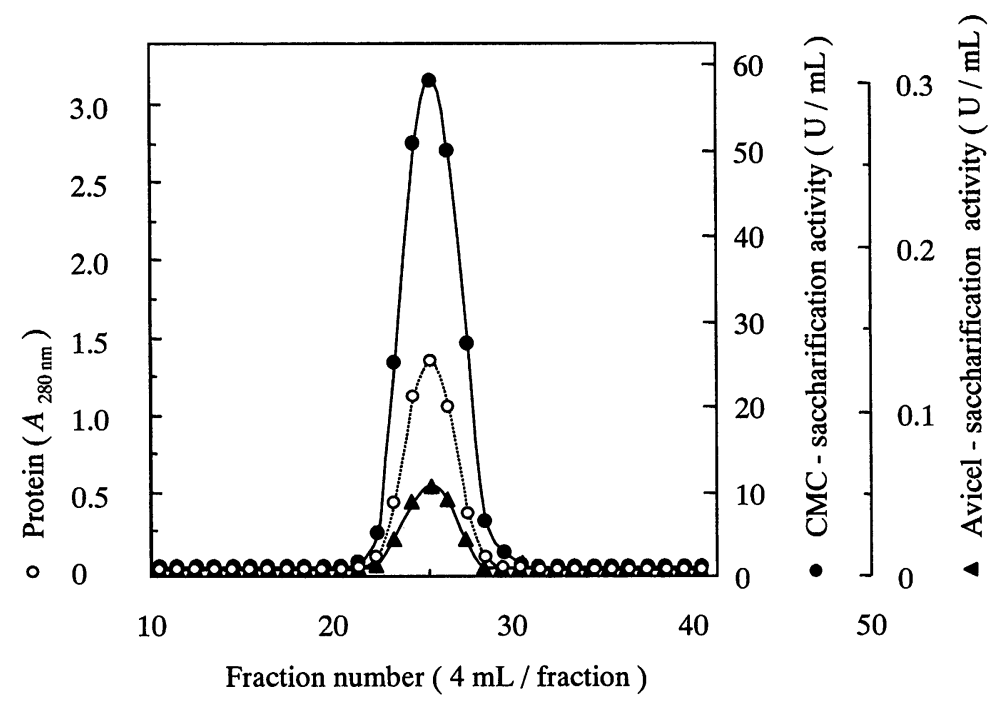

Fig. 2. Gel filtration profiles of the cellulase fractions on Bio-Gel P-100 after Butyl-Toyopearl 650M column chromatography.

$\bigcirc$, protein $\left(A_{280 \mathrm{~nm}}\right) ; \boldsymbol{\ominus}, \mathrm{CMC}$-saccharification activity $(\mathrm{U} / \mathrm{mg}$ protein) $; \boldsymbol{\Delta}$, Avicel-saccharification activity (U/mg protein). 
Table 1. Summary of the purification of cellulase IV from Acremonium cellulolyticus.

\begin{tabular}{lcccrr}
\hline Purification step & $\begin{array}{c}\text { Total protein } \\
(\mathrm{mg})\end{array}$ & $\begin{array}{c}\text { Total activity } \\
(\mathrm{U})\end{array}$ & $\begin{array}{c}\text { Specific activity }^{b} \\
(\mathrm{U} / \mathrm{mg})\end{array}$ & $\begin{array}{c}\text { Yield } \\
(\%)\end{array}$ & $\begin{array}{c}\text { Purification } \\
(\text { fold })\end{array}$ \\
\hline 1. Crude cellulase extract & 3750.0 & 29325.0 & 7.8 & 100.0 & 1.0 \\
2. QAE-Toyopearl 550C & 407.9 & 7520.7 & 18.4 & 25.6 & 2.4 \\
3. DEAE-Toyopearl 650S & 132.4 & 6829.7 & 51.6 & 23.3 & 6.6 \\
4. Butyl-Toyopearl 650M & 99.1 & 6698.8 & 67.6 & 22.8 & 8.7 \\
5. Bio-Gel P-100 & 61.9 & 6557.1 & 105.9 & 22.4 & 13.6 \\
\hline
\end{tabular}

${ }^{a}$ Measured by the method of Lowry et al. ${ }^{11)}{ }^{b} \mathrm{CMC}$ was used as a substrate.

only cellulase activity was obtained (Fig. 2). The active fractions were then combined as the purified enzyme. The purified enzyme gave a single protein band on both Native- and SDS-PAGE, and was designated as cellulase IV.

Table 1 summarizes the yield and specific activity of cellulase IV during the purification procedure. Cellulase IV had a high level of specific activity, about $106 \mathrm{U} / \mathrm{mg}$ of protein in a final yield of about $22 \%$, and was used for the subsequent characterization.

\section{Physicochemical properties of the purified en- zyme.}

The molecular mass of cellulase IV was found to be about $38 \mathrm{kDa}$ by comparison of its relative mobility on SDS-PAGE with those of standard proteins (Fig. 3). About $1.3 \%$ carbohydrate moiety seemed to be associated with the enzyme protein. The isoelectric point of the enzyme determined by isoelectric focusing was $\leqq 3.4$. Concerning the $\mathrm{N}$ terminal amino acid sequence of the purified enzyme, the first amino acid by Edman degradation was not detected, indicating the presence of a modified amino acid residue at the $\mathrm{N}$-terminus. Pyroglutamic acid was strongly suggested as the $\mathrm{N}$-terminus amino acid judging from the result of pyroglutamate aminopeptidase treatment. The $\mathrm{N}$ terminal amino acid sequence from the 2 nd up to the 27th residue of cellulase IV was determined to be: Gln-Ala-Ser-(Cys)-Phe-Glu-Trp-Phe-Gly-SerAsn-Glu-Ser-Gly-Ala-Glu-Phe-Gly-Ser-Gly-AsnIle-Pro-Gly-Val-Glu-.

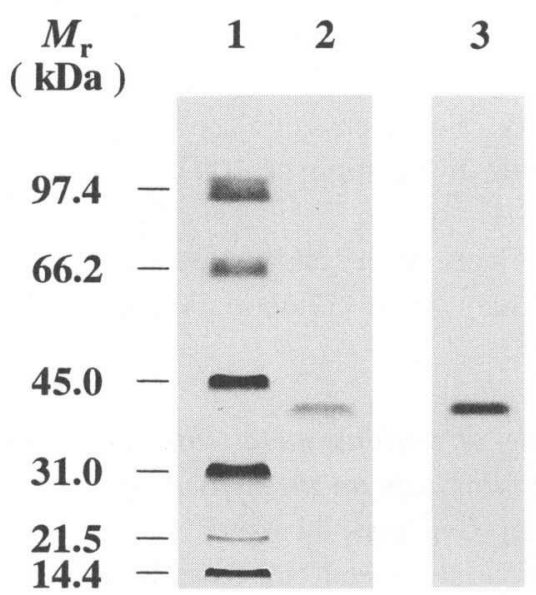

Fig. 3. Native- and SDS-PAGE of the purified enzyme.

Lane 1, standard protein mixture containing phosphorylase $b(97.4 \mathrm{kDa})$, bovine serum albumin (66.2), ovalbumin (45.0), carbonic anhydrase (31.0), soybean trypsin inhibitor (21.5), and lysozyme (14.4); Lanes 2 and 3, purified enzyme on SDS- and Native-PAGE, respectively.

\section{Effects of $\mathrm{pH}$ and temperature on the enzyme activity and stability.}

The effects of $\mathrm{pH}$ and temperature on the activity of the purified enzyme were studied under standard assay conditions at $30^{\circ} \mathrm{C}$ for $10 \mathrm{~min}$ using $50 \mathrm{~mm}$ Mcllvaine buffer at $\mathrm{pH} \quad 2.7-8.2$ and at different reaction temperatures for $10 \mathrm{~min}$. Cellulase IV showed a single maximum at $\mathrm{pH} 4.0$ and $60^{\circ} \mathrm{C}$.

On the other hand, each solution containing an equal amount of the purified enzyme $(0.01 \mathrm{U})$ was individually adjusted to a $\mathrm{pH}$ from 2.7 to 12.0 by adding $50 \mathrm{mM}$ McIlvaine or Britton-Robinson buffer. After the buffered enzyme solutions had been kept at $4{ }^{\circ} \mathrm{C}$ for $24 \mathrm{~h}$, they were diluted 25 fold with $50 \mathrm{mM}$ McIlvaine buffer ( $\mathrm{pH} 4.0$ ). Each $0.25 \mathrm{~mL}$ enzyme sample was then examined for 
remaining $\mathrm{CMC}$-saccharification activity by the standard assay at $30^{\circ} \mathrm{C}$ for $10 \mathrm{~min}$. Cellulase IV was completely stable over the range of $\mathrm{pH} 5.0^{-}$ 12.0 at $4^{\circ} \mathrm{C}$ for $24 \mathrm{~h}$.

The purified enzyme in $50 \mathrm{~mm}$ Mcllvaine buffer ( $\mathrm{pH} 4.0$ ) was heated at various temperatures for 10 min, then cooled immediately in an ice-bath. The remaining CMC-saccharification activity was then measured with $0.25 \mathrm{~mL}$ of each enzyme solution by the standard assay at $30^{\circ} \mathrm{C}$ for $10 \mathrm{~min}$. The enzyme was completely stable at temperatures below $50{ }^{\circ} \mathrm{C}$. The enzyme retained about 25 and $5 \%$ of its original activity on heating at 80 and $90^{\circ} \mathrm{C}$, respectively. However, cellulase IV was completely inactivated by heating at $100^{\circ} \mathrm{C}$ under the conditions used.

The effects of $\mathrm{pH}$ and temperature on the activity and stability of cellulase IV are shown in Fig. $4 \mathrm{~A}$ and $\mathrm{B}$.

Effects of various metal ions and several enzyme inhibitors on the activity of the enzyme.

The enzyme was incubated with an equal volume of each metal ion or inhibitor solution (10 $\mathrm{mm}, \mathrm{pH} 6.0$ ) at $30^{\circ} \mathrm{C}$ for $30 \mathrm{~min}$. Then the mixtures were diluted 25-fold with $50 \mathrm{mM}$ McIlvaine buffer ( $\mathrm{pH} 4.0$ ), and the remaining enzyme activity per milliliter of each reaction mixture containing $0.34 \mathrm{U}$ of enzyme was examined by the standard assay at $30^{\circ} \mathrm{C}$ for $10 \mathrm{~min}$. Inactivation of the enzyme was found to be partial with $5 \mathrm{mM}$ $\mathrm{Ba}^{2+}, \mathrm{Cu}^{2+}, \mathrm{Sr}^{2+}$ and $\mathrm{Ag}^{+}$being about 10, 15, 20 and $25 \%$ inhibition, respectively and with $5 \mathrm{~mm}$ NBS being about $15 \%$ inhibition. On the other hand, $5 \mathrm{mM} \mathrm{Hg}^{2+}, \mathrm{Fe}^{3+}$ or $\mathrm{KMnO}_{4}$ inactivated the enzyme completely. $\mathrm{Pb}^{2+}$, EDTA and the sulfhydryl reagents tested had no inhibitory effect on the activity of the enzyme.

\section{Mode of action of the enzyme toward CMC.}

The mode of action of cellulase IV toward CMC was analyzed by a viscometer. The reaction mixture was composed of $6 \mathrm{~mL}$ of $50 \mathrm{~mm}$ acetate buffer ( $\mathrm{pH} 4.0$ ) containing $0.5 \% \mathrm{CMC}$ and $6 \mathrm{~mL}$ of the enzyme solution (0.09 U). The mixture was incubated in a Cannon-Fenske viscometer at $30^{\circ} \mathrm{C}$. The decrease in viscosity of the incubation mixture and formation of reducing sugars were measured every $5 \mathrm{~min}$. Then the increases in specific fluidity ( $\phi_{\text {sp. }}$ ) were plotted against the increases in reducing power. As can be seen in Fig. 5, a straight line with the slope of an angle of about $45^{\circ}$ was obtained for the enzyme. This result indicates that the purified enzyme is a medium endo-type cellulase. The differences in slopes produced by cellulase IV and the crude enzyme suggest that the crude enzyme preparation contains other cellulase components other than the present one.
(A)

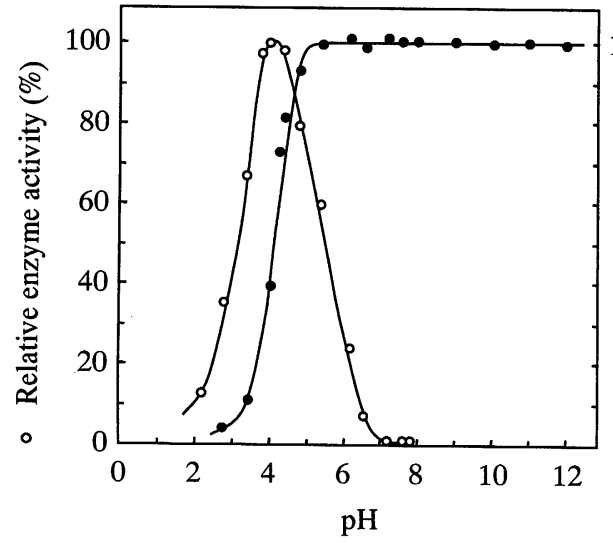

(B)

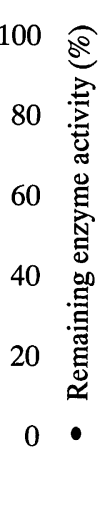

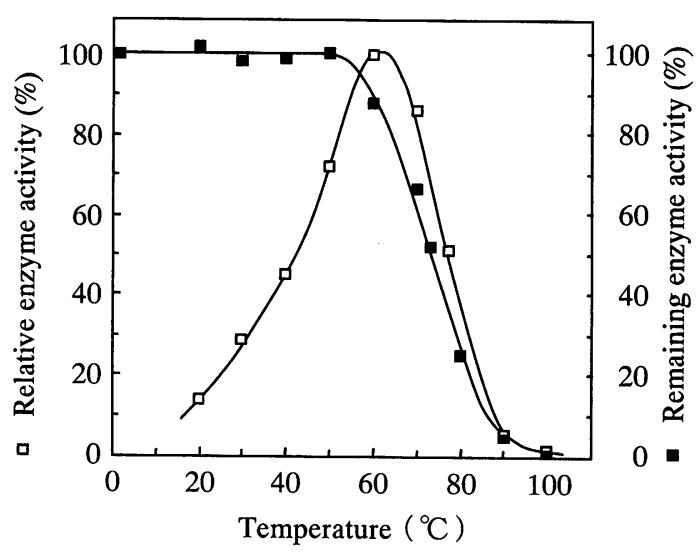

Fig. 4. Effects of $\mathrm{pH}$ and temperature on the activity and stability of the purified enzyme.

(A) $\bigcirc, \mathrm{pH}$ activity; $\bigcirc, \mathrm{pH}$ stability. (B) $\square$, thermal activity; $\mathbf{\square}$, thermal stability. Experimental details are given in the text. 
Action of the purified enzyme on cellooligosaccharides and insoluble substrates.

The hydrolysis products from cellooligosaccharides by cellulase IV were analyzed by HPLC. Table 2 shows the degree of hydrolysis and product distribution due to the action of cellulase IV at the initial and late stages of incubation. The enzyme hydrolyzed $G_{6}, G_{5}$ and $G_{4}$ to give $G_{2}$ as the major end product. However, $\mathrm{G}_{3}$ was considerably hard to hydrolyze compared to $\mathrm{G}_{4}-\mathrm{G}_{6}$. The enzyme did not act entirely on $\mathrm{G}_{2}$.

Avicel, filter paper and dewaxed cotton were used as insoluble substrates. The reaction mixture

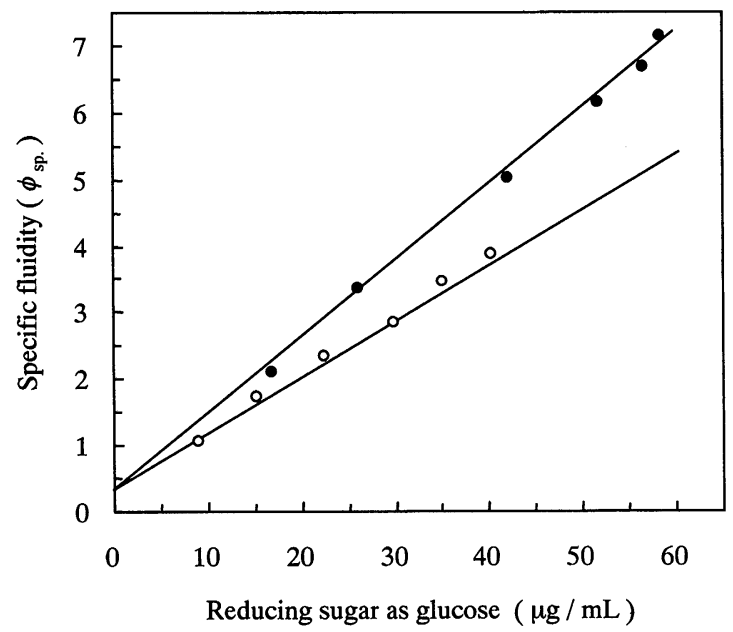

Fig. 5. Relationship between increases in fluidity and reducing power during the hydrolysis of $\mathrm{CMC}$ by the purified enzyme and crude enzyme.

-, purified enzyme; $\bigcirc$, crude enzyme. contained $40 \mathrm{mg}$ of each substrate and $2 \mathrm{~mL}$ of purified enzyme $(2.7 \mathrm{U})$ in $50 \mathrm{mM}$ acetate buffer ( $\mathrm{pH} 4.0$ ). Incubation was done at $40^{\circ} \mathrm{C}$ for an appropriate period. The reaction was stopped by adding $20 \mu \mathrm{L}$ of $2 \mathrm{~N} \mathrm{NaOH}$ solution. Reducing sugars produced were measured as in the case of Avicelsaccharification activity. Glucose formed in the reaction mixture was measured by the method of glucose oxidase. ${ }^{16,17)}$

As shown in Fig. 6, it is clear that cellulase IV produces a high level of reducing sugars and a small amount of glucose from both Avicel and filter paper. On the other hand, dewaxed cotton was hard to hydrolyze using this enzyme in a shorttime incubation. HPLC analysis indicated that most reducing sugars produced were $\mathrm{G}_{2}$. After prolonged incubation $\left(40^{\circ} \mathrm{C}, 7\right.$ days), the enzyme split insoluble substrates tested to give predominant $\mathrm{G}_{2}$ and a small amount of $G_{1}$ as the final hydrolysis products (data not shown).

\section{DISCUSSION}

An endo-cellulase from a commercial cellulase preparation of Acremonium cellulolyticus was extensively purified by consecutive column chromatographies using QAE-Toyopearl 550C, DEAEToyopearl 650S, Butyl-Toyopearl 650M and BioGel P-100. The purified enzyme (Cellulase IV) was homogeneous on both Native- and SDSPAGE, and was completely free from $\beta$-glucosidase. Cellulase IV showed a high specific activity

Table 2. Degree of hydrolysis and product distribution due to the action of cellulase IV at the initial and late stages of incubation.

\begin{tabular}{|c|c|c|c|c|c|c|c|c|}
\hline \multirow{2}{*}{$\begin{array}{l}\text { Substrate } \\
(4 \mathrm{mM})\end{array}$} & \multirow{2}{*}{$\begin{array}{l}\text { Degree of hydrolysis }{ }^{a} \\
(\%)\end{array}$} & \multirow{2}{*}{$\begin{array}{l}\text { Time } \\
\text { (min) }\end{array}$} & \multicolumn{6}{|c|}{ Product distribution (mM) } \\
\hline & & & $\mathrm{G}_{6}$ & $\mathrm{G}_{5}$ & $\mathrm{G}_{4}$ & $\mathrm{G}_{3}$ & $\mathrm{G}_{2}$ & $\mathrm{G}_{1}$ \\
\hline \multirow{2}{*}{ Cellohexaose } & 97.0 & 2 & 0.12 & 0.10 & 1.94 & 1.74 & 4.46 & 0.14 \\
\hline & 100.0 & 240 & - & 0.06 & 0.59 & 1.85 & 7.11 & 0.73 \\
\hline \multirow{2}{*}{ Cellopentaose } & 95.0 & 2 & - & 0.20 & 0.80 & 2.02 & 4.56 & 0.10 \\
\hline & 100.0 & 240 & - & - & 0.27 & 1.83 & 6.13 & 0.54 \\
\hline \multirow{2}{*}{ Cellotetraose } & 9.3 & 10 & - & - & 3.63 & 0.19 & 0.34 & 0.09 \\
\hline & 72.3 & 240 & - & - & 1.11 & 1.00 & 3.61 & 0.85 \\
\hline Cellotriose & 6.5 & 240 & - & - & - & 3.74 & 0.30 & 0.05 \\
\hline
\end{tabular}

${ }^{a}$ Calculated from the amount of residual substrate. 


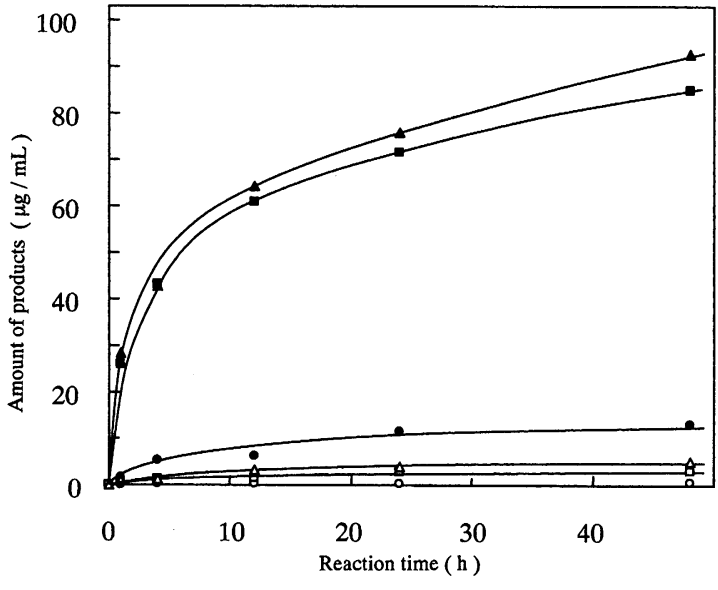

Fig. 6. Courses of reducing sugar and glucose formation due to the action of the purified enzyme on insoluble substrates. - reducing sugar from dewaxed cotton; $\bigcirc$, glucose from dewaxed cotton; $\mathbf{\square}$, reducing sugar from filter paper; $\square$, glucose from filter paper; $\mathbf{\Delta}$, reducing sugar from Avicel; $\triangle$, glucose from Avicel.

for $\mathrm{CMC}$ and extremely low specific activity for

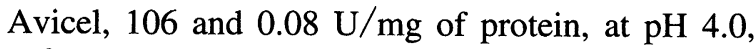
$30^{\circ} \mathrm{C}$ for $\mathrm{CMC}$ and $40^{\circ} \mathrm{C}$ for Avicel, respectively.

Our purified cellulase is extremely close in many points to FV CM-cellulase from Aspergillus aculeatus $^{18)}$ which possesses the following properties: molecular mass, $38 \mathrm{kDa}$; $\mathrm{pI}, 3.4$; optimum $\mathrm{pH}, 4.0$; optimum temperature, $65^{\circ} \mathrm{C} ; \mathrm{pH}$ stability, $\mathrm{pH} 3.5-9.0$; and thermal stability, $\leqq 50^{\circ} \mathrm{C}$. The present enzyme also fairly closely resembles an endo-type cellulase from Aspergillus niger ${ }^{19)}$ which has the characteristic properties of molecular mass, $31 \mathrm{kDa}$; $\mathrm{pI}, 3.67$; specific activity for $\mathrm{CMC}, 117$ $\mathrm{U} / \mathrm{mg}$ of protein; optimum $\mathrm{pH}, 4.0$ and $\mathrm{pH}$ stability, $\mathrm{pH}$ 5.0-8.0. However, the purified cellulase was extremely stable in the alkaline region (Fig. 4 A) compared to the above two Aspergillus cellulases.

Inactivation of the enzyme by the metal ions tested was found to be partial with $5 \mathrm{mM} \mathrm{Ba}^{2+}$, $\mathrm{Cu}^{2+}, \mathrm{Sr}^{2+}$ and $\mathrm{Ag}^{+}$, corresponding to about 10 , 15,20 , and $25 \%$ inhibition, respectively. However, no inhibition of the purified enzyme was observed with EDTA or the sulfhydryl reagents tested. This suggests that the metals and sulfhydryl groups are not essential for the cellulolytic action of the en- zyme, as is also the case with highly purified cellulases from $T$. viride. ${ }^{3,5)}$

During the hydrolysis of CMC by cellulase components, there is usually a characteristic pattern in the relationship between loss of viscosity and increase in reducing power. Consequently, when the increases in specific fluidity $\left(\phi_{\text {sp. }}\right)$ in the enzymic reaction are plotted against increases in reducing power, the slopes of the resulting curves are different. It has been reported that the highly purified cellulase components from $T$. viride ${ }^{3,5)}$ and Irpex lacteus ${ }^{20)}$ have the different degrees of randomness during the hydrolysis of CMC. In comparison with these data, cellulase IV was characterized as a medium endo-type cellulase.

The enzyme was incapable of attacking either $\mathrm{G}_{2}$ or PNPG, but hydrolyzed various cellulosic substratres such as cellooligosaccharides $\left(\mathrm{G}_{3}-\mathrm{G}_{6}\right)$, $\mathrm{CMC}$, Avicel, filter paper, and dewaxed cotton to various extents. $G_{3}$ was only slightly attacked using a fairly large amount of enzyme. $\mathrm{G}_{4}$ was hydrolyzed much more slowly by the enzyme than $\mathrm{G}_{5}$ and $\mathrm{G}_{6}$. As can be seen in Table 2, cellulase IV split $G_{3}$ to give $G_{2}$ and $G_{1}$. However, the amount of $G_{2}$ is 6 times higher than that of $G_{1}$. This strongly suggests that the catalytic reaction is not a simple hydrolysis but a reaction involved in transglycosylation. In either case, the mode of action of cellulase IV on cellooligosaccharides was extremely similar to that of an endo-cellulase from A. niger. ${ }^{19)}$

The authors wish to express their gratitude to Ms. Naomi Sumida of the Pharmaceutical Technology Laboratories of Meiji Seika Kaisha, Ltd. for her help in conducting amino acid sequence analyses.

\section{REFERENCES}

1) T.M. Wood and S.I. McCrae: Synergism between enzymes involved in the solubilization of native cellulose. Adv. Chem. Ser., 181, 181-209 (1979).

2 ) G. Okada, K. Nisizawa and H. Suzuki : Cellulase components from Trichoderma viride. J. Biochem., 63, 591-607 (1968).

3 ) G. Okada: Enzymatic studies on a cellulase system of Trichoderma viride II. Purification and properties of two cellulases. J. Biochem., 77, 33-42 (1975).

4 ) G. Okada and K. Nisizawa: Enzymatic studies on a 
cellulase system of Trichoderma viride III. Transglycosylation properties of two cellulase components of random type. J. Biochem., 78, 297-306 (1975).

5 ) G. Okada: Enzymatic studies on a cellulase system of Trichoderma viride IV. Purification and properties of a less-random type cellulase. J. Biochem., 80, 913922 (1976).

6 ) G. Okada and Y. Tanaka: A novel type of cellulase from Trichoderma viride. Agric. Biol. Chem., 52, 617-619 (1988).

7 ) G. Okada and Y. Tanaka: Nonexistence of exo-cellobiohydrolase (CBH) in the cellulase system of Trichoderma viride. Agric. Biol. Chem., 52, 2981-2984 (1988).

8 ) G. Okada: A novel concept for the enzymatic degradation mechanism of native cellulose. in Genetics, Biochemistry and Ecology of Cellulose Degradation, K. Ohmiya, K. Hayashi, K. Sakka, Y. Kobayashi and S. Karita, eds., Uni Publishers Co., Ltd., Tokyo, p. 76(1999).

9 ) M. Somogyi: Note on sugar determination. J. Biol. Chem. , 195, 19-23 (1952).

10) N. Nelson : A photometric adaptation of the Somogyi method for the determination of glucose. J. Biol. Chem., 153, 375-380 (1944).

11) O.H. Lowry, N.J. Rosebrough, A.L. Farr and R.J. Randall: Protein measurement with the Folin phenol reagent. J. Biol. Chem., 193, 265-275 (1951).

12) M. Dubois, K.A. Gilles, J.K. Hamilton, P.A. Rebers and F. Smith: Colorimetric method for determination of sugars and related substances. Anal. Chem., 28, 350-356 (1956).

13) B.J. Davis: Disc electrophoresis-II. Method and application of human serum proteins. Ann. N.Y. Acad. Sci., 121, 404-427 (1964).

14) U.K. Laemmli: Cleavage of structural proteins during the assembly of the head of bacteriophage T4. Nature, 227, 680-685 (1970).

15) O. Vesterberg: Isoelectric focusing of proteins in thin layers of polyacrylamide gel. Sci. Tools, 20, 22-29 (1973).

16) N.M. Papadopoulos and W.C. Hess: Determination of neuraminic (sialic) acid, glucose and fructose in spinal fluid. Arch. Biochem. Biophys., 88, 167-171 (1960).

17) A. Dahlqvist: Determination of maltase and isomaltase activities with a glucose-oxidase reagent. Biochem. J., 80, 547-551 (1961).

18) S. Murao, R. Sakamoto and M. Arai: Cellulases of Aspergillus aculeatus. Methods Enzymol., 160, 274299 (1988).

19) G. Okada: Purification and properties of a cellulase from Aspergillus niger. Agric. Biol. Chem., 49, 1257-
1265 (1985).

20) T. Kanda, S. Nakakubo, K. Wakabayashi and $K$. Nisizawa: The mode of enzymatic degradation of cellulose based on the properties of cellulase components. Adv. Chem. Ser., 181, 211-236 (1979).

(Received February 24, 2000; Accepted March 6, 2000)

$$
\begin{gathered}
\text { 糸状菌 Acremonium cellulolyticus 起源の } \\
\text { エンドセルラーゼの精製と基本性質 } \\
\text { キャンサーン スパンニー1, 松下直由 }{ }^{2}, \\
\text { 河野敏明 }{ }^{3}, \text { 岡田嚴太郎 }{ }^{1,2} \\
1 \text { 静岡大学大学院電子科学研究科 } \\
(432-8561 \text { 浜松市城北 3-5-1) } \\
2 \text { 静岡大学教育学部 } \\
\text { (422-8529 静岡市大谷 836) } \\
3 \text { 明治製菓株式会社生物科学研究所 } \\
(350-0289 \text { 坂戸市千代田 5-3-1) }
\end{gathered}
$$

糸状菌 Acremonium cellulolyticus の市販酵素製剤か ら,エンドセルラーゼの一成分を QAE-Toyopearl 550C, DEAE-Toyopearl 650S, Butyl-Toyopearl 650M および Bio-Gel P-100のカラムクロマトグラフィーを順次行 い, 電気泳動的に単一になるまで精製し，セルラーゼ IV と呼称した。精製酵素は CMCに対し高い比活性值 (106 U/mg) を，またAvicel に対しきわめて低い比活 性值 $(0.08 \mathrm{U} / \mathrm{mg})$ を示した. 当該酵素の分子質量およ び等電点は，それぞれ約 $38 \mathrm{kDa}$ およ゙ 3.4 以下で あった．セルラーゼ IV の $\mathrm{N}$ 末端側第 2-第 27 アミノ 酸残基の配列は, Gln-Ala-Ser-(Cys)-Phe-Glu-Trp-PheGly-Ser-Asn-Glu-Ser-Gly-Ala-Glu-Phe-Gly-Ser-Gly-AsnIle-Pro-Gly-Val-Glu-であった. 本酵素の反応至適 $\mathrm{pH}$

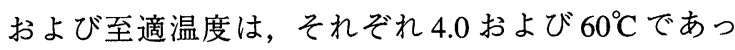
た. セルラーゼ IV は各種の $\mathrm{pH} て ゙ ~ 4^{\circ} \mathrm{C}, 24$ 時間処理 した場合には $\mathrm{pH}$ 5.0-12.0の範囲で，また 50 C 以下に おいてそれぞれ安定であった. CMC および各種のセ ロオリゴ糖に対する作用パターンから, 当該酵素の作 用様式は，中位のエンド型であることが判明した．本 酵素の活性発現は, $5 \mathrm{mM}$ の $\mathrm{Hg}^{2+}, \mathrm{Fe}^{3+}$ おび $\mathrm{KMnO}_{4}$ により完全に阻害された。 セルラーゼ IVを各 種の不溶性セルロースに作用させると, 多量のセロビ オースおよび少量のグルコースが, 最終生成糖として 得られた。 